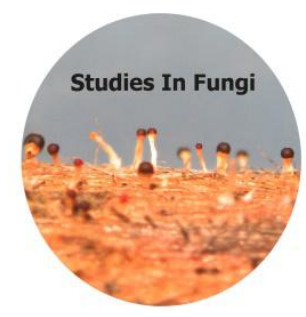

\title{
Article
}

\author{
Doi 10.5943/sif/2/1/7 \\ Copyright $\odot$ Mushroom Research Foundation
}

\section{Phallus rubicundus in South Brazil}

\section{Cortez VG ${ }^{1}$ and Silva-Filho AGS ${ }^{2}$}

${ }^{1}$ Universidade Federal do Paraná, Departamento de Biodiversidade, Palotina, Paraná, Brazil
${ }^{2}$ Universidade Federal do Paraná, Programa de Pós-graduação em Botânica, Curitiba, Paraná, Brazil

Cortez VG, Silva-Filho AGS 2017 - Phallus rubicundus in South Brazil. Studies in Fungi 2(1), 5963, Doi 10.5943/sif/2/1/7

\begin{abstract}
The widespread phalloid fungus Phallus rubicundus is reported for the first time in South Brazil. The collection is described and illustrated macro- and micromorphologically, and the taxonomy, distribution and ecology of the species are discussed, as well its occurrence in Brazil.
\end{abstract}

Key words - Phallales - Phallomycetidae - Phallus subgenus Satyrus - Stinkhorns

\section{Introduction}

Phalloid fungi (Phallales, Phallomycetidae) have aroused interest of researchers in the last decade in South Brazil, where several new records and rediscoveries have been reported (e.g. Meijer 2006, Trierveiler-Pereira et al. 2009, 2014a, 2014b, Cortez et al. 2011a, 2011b, Magnago et al. 2013, Sulzbacher et al. 2013, Cortez \& Rossoni 2014, Alves \& Cortez 2016). A summary of the current knowledge on Brazilian phalloids is given by Trierveiler-Pereira (2015). Despite the growing investigations on these peculiar mushrooms, further fieldwork has revealed more surprising findings, supporting the need for broad exploration of the Brazilian mycobiota.

In the present contribution, we report the collection of noteworthy phalloid fungi, not previously reported from South Brazil. Our aim is to improve the knowledge on the south Brazilian mycobiota, especially the phalloid species, and provide detailed a description and illustrations of this material, as well a discussion on the taxonomic limits, ecology and distribution.

\section{Materials \& Methods}

Specimens were collected in the Campus of Universidade Federal do Paraná (24¹7'34.14"S, 53 $\left.50^{\prime} 31.41^{\prime \prime W}\right)$, municipality of Palotina, Paraná State, South Brazil. The collection was gathered near a small fragment of Seasonal Semi-decidual Forest, which is the typical vegetation of the western region of Paraná State, inserted in the Atlantic Forest Biome. Morphological analysis (both macro- and microscopical) followed standard procedures for phalloid fungi (Miller \& Miller 1988). Colour names and codes adopted in the descriptions of macroscopic features are from Kornerup \& Wanscher (1978). Micrographs were obtained with an Olympus CX31 light microscope, with a Toup Cam FMA050 digital camera, and microscopic measurements were taken through the Toup View 3.7 software. In the basidiospores description, Q is the quotient between the length and width, $\mathrm{Qm}$ is the medium value of $\mathrm{Q}$, and $\mathrm{n}$ is the number of measured basidiospores/ number of analyzed basidiomata/ number of collections. Collected specimens are preserved at the Herbarium of Campus Palotina (HCP), Universidade Federal do Paraná. In addition, material of P. rubicundus preserved at the Herbarium of Instituto de Botânica (SP) was loaned for comparison. 


\section{Results}

Phallus rubicundus (Bosc) Fr., Syst. Mycol. 2, 284 (1823)

三Satyrus rubicundus Bosc, Mag. Gesell. Naturf. Freunde, Berlin 5, 86 (1811)

Fig. 1

$=$ Phallus sanguineus Henn., Bot. Jahrb. Syst. Pflanzengesch. Pflanzengeogr. 30, 57 (1901)

$=$ Phallus gracilis (E. Fisch.) Lloyd, Mycol. Writ. 7, 8 (1907)

Immature specimens ('mycoeggs') not observed. Basidiomata 133-166 × 19-21 mm, when expanded, tall, sub-cylindrical, slightly curved or erect. Pileus 25-29 $\times 4-5 \mathrm{~mm}$, ellipsoidal to conical-campanulate, apex truncate, free (not covered by the slimy gleba), the tip 1-2 mm diameter, pastel red (7A4), surface rugulose to pored. Pseudostipe 81-99 × 6-7 mm (apex), 9-11 mm (base), cylindrical, straight to slightly curved, spongy, greyish red (7B5) to pastel red (7A4) at the apex, light orange (6A4) to pale orange (6A3) discolored at the base, pale yellow (1A3) to yellowish with (1A2) at the base, hollow. Gleba covering partially the pileus, ca. $3 / 4$ of total length, slimy mucilaginous, olive (1F4) to (1F8). Volva 18-30 × 19-21 mm, saccate, white (1A1). Rhizomorphs not numerous and short, up to $12 \mathrm{~mm}$ long, thin, white (1A1).

Basidiospores 3.5-4 × 1.5-2 $\mu \mathrm{m}, \mathrm{Q}=1.8-2.53, \mathrm{Qm}=2.14, \mathrm{n}=40 / 2 / 1$, ellipsoid, smooth and thin-walled, greenish in $\mathrm{KOH}$. Basidia not found. Pileus hyphae 1.2-4.7 $\mu \mathrm{m}$ diam., cylindrical, some branched, smooth or rarely incrusted, hyaline in $\mathrm{KOH}$, without clamp-connections. Pseudostipe formed of globose, isodiametric to irregular subglobose hyphae, 26-59.2 × 19.5-52.9 $\mu \mathrm{m}$ diameter, smooth and thin-walled, hyaline in $\mathrm{KOH}$. Volva composed of filamentous hyphae, 1.4-3 $\mu \mathrm{m}$ diameter, smooth, with clamp-connection, hyaline in $\mathrm{KOH}$. Rhizomorph hyphae 1.5-2.8 $\mu \mathrm{m}$ diameter, smooth, with clamp-connection, hyaline in $\mathrm{KOH}$. Clamp-connections present in most septa.

Material examined - BRAZIL, Paraná State, Palotina, Universidade Federal do Paraná, Campus Palotina, 30 November 2015, collected by V.G. Cortez (HCP 1034); São Paulo State, Cananeia, Parque Estadual Ilha do Cardoso, November 1982, collected and determined by V.L.R. Bononi (SP-Fungi 178206).

Habitat and distribution: in small groups, on the ground, among woodchips and fallen fruits of Parapitadenia rigida (Benth.) Brenan (Leguminosae, Mimosoideae). Widely distributed in tropical and subtropical zones of the world: Africa (Dring 1964), Australia (Grgurinovic 1997), Asia (Kour et al. 2016), North America (Hemmes \& Desjardin 2002), and Europe (Calonge 1998). From Brazil, it was recorded only once in sandbank vegetation in Atlantic Forest biome, São Paulo State (Bononi et al. 1984). First record from South Brazil and Seasonal Semidecidual Forest.

\section{Discussion}

Phallus rubicundus is the type species of the genus Satyrus Bosc, which Kreisel (1996) considered as a subgenus Satyrus (Bosc) Kreisel, in a broader concept of the genus Phallus. According to Kreisel (1996), the following diagnostic features of this subgenus are: small basidiomata, with a Mutinus-like stature, pileus varying from campanulate, acute to obtuse or truncate, with a granulate, rugulose or merulioid surface, absence of indusium and pseudostipe with conspicuous yellow, orange, or red colors.

Calonge (2005) presented a preliminary key for the worldwide species of Phallus sensu lato and, although not mentioning the name Satyrus in the synonyms list, seems to agree with Kreisel's statement of synonymy with Phallus. On P. rubicundus, Calonge (2005) applied a broader concept of that species, including P. rugulosus (E. Fischer) O. Kuntze and P. novae-hollandiae Corda, two species that Kreisel (1996) considered distinct from P. rubicundus. Grgurinovic (1997) presented an extensive list of synonyms, most of them Australian names described by mycologists like E. Fischer, P. Hennings, C.G. Lloyd, F.M. Bailey, and others. The numerous synonyms obviously reflect the high variability of this phalloid, especially regarding the size and color variation of the basidiomata, which are the most used features to distinguish taxa in the group (Dring 1964).

Many authors mention the confusion of P. rubicundus with members of the genus Mutinus (e.g. Kour et al. 2016), especially by virtue of the tall basidiomata, with a not so conspicuous pileus - whose presence is the main distinguishing feature of Phallus, and absent in Mutinus 
(Calonge 1998). A simple internet search for Mutinus spp. or P. rubicundus terms reveals a sort of confusion and numerous misidentifications in blogs and websites throughout the world.

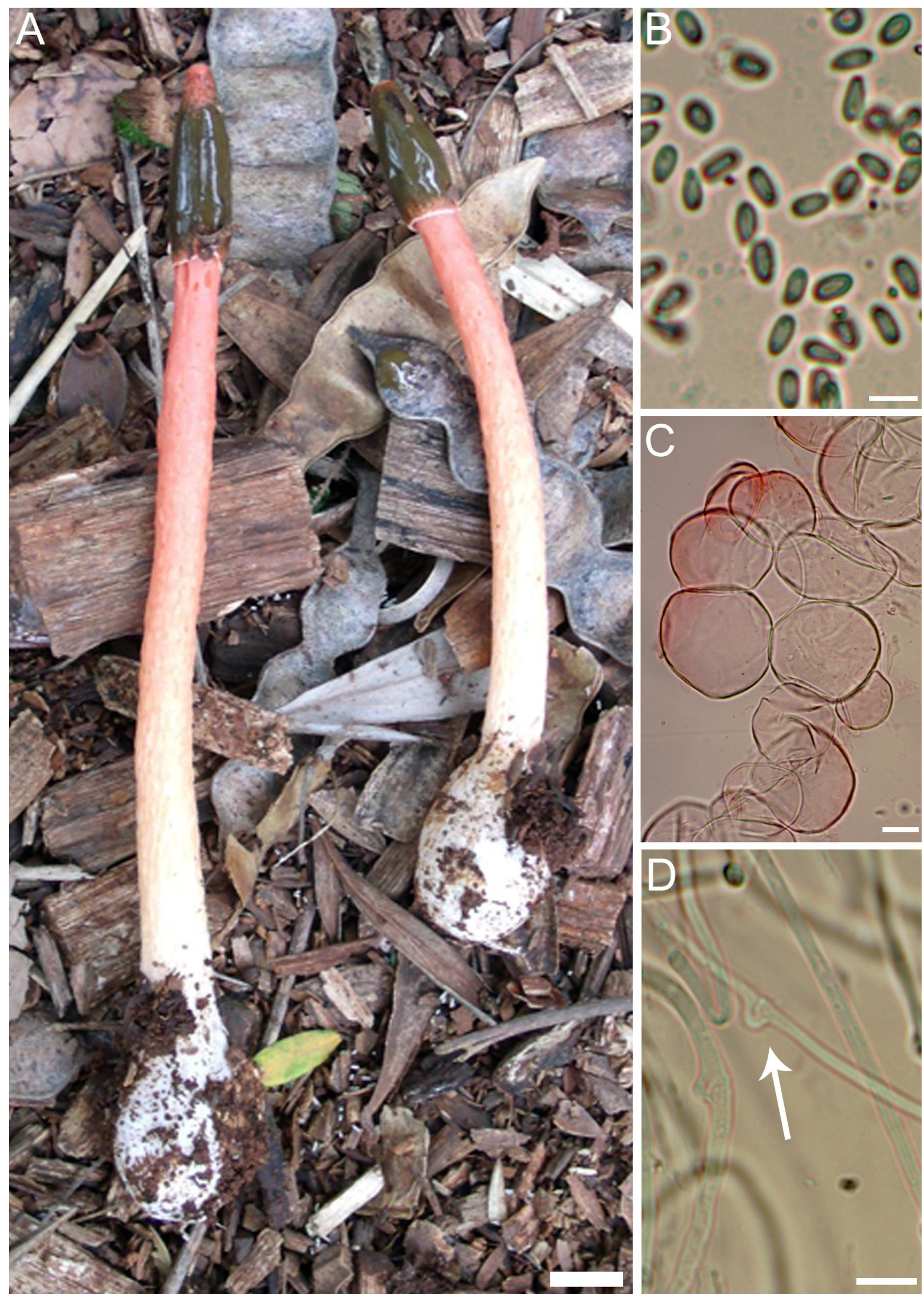

Fig. 1 - Phallus rubicundus. A Basidiomata. B Basidiospores. C Pseudostipe hyphae. D Hyphae from rhizomorphs with clamp connection (arrow). Bars: $A=10 \mathrm{~mm}$. B-E $=10 \mu \mathrm{m}$. Photographs: A by V.G. Cortez, B-D by AGS Silva-Filho. 
Regarding the ecological aspects, the species has been reported from several habitats, varying from lawns, gardens, farms and forest parks. Hemmes \& Desjardin $(2002,2009)$ reported it as common on woodchips in Hawaii; our material was also growing near the base of a very rotten stump, on soil covered by numerous wood chips and fallen fruits (legumes) of Parapitadenia rigida (Figure 1A), in full accordance with the observations of these authors.

Our material is very similar to that illustrated by Calonge $(1998,2005)$, regarding the size, stature and colors of the basidiomata. Microscopically, the basidiospores exhibited a small degree of variation. Our observations are in agreement to those of Calonge (1998) and Dring (1964), who reported basidiospores 3.5-5 × 1.5-2.5 $\mu \mathrm{m}$.

Regarding the distribution of the species, it is poorly known in South America and Brazil. The study of South Brazilian phalloid fungi started with contributions by Braun (1932) and Rick (1961), but no similar or synonymous species were reported by these authors. The only known record of this phalloid in the Brazilian territory was published by Bononi et al (1984), from the State of São Paulo. Unfortunately, the material loaned from Herbarium SP, is not in good condition and did not allow a conclusion regarding its identification.

It can be assumed that $P$. rubicundus is not a common stinkhorn in South America, and may represent to a recent introduction, considering the scattered reports from Brazil. Even in the South American countries with recognized mycological activity (especially on phalloids), as Argentina, Chile, Paraguay, Suriname and Venezuela, there are not known reports for P. rubicundus or some of its numerous synonyms (Spegazzini 1887, Fischer 1928, Dennis 1953, Wright 1960, SandovalLeiva et al. 2014). Thus, future collections are expected to expand the knowledge on the distribution of this species in Brazil and South America.

\section{Acknowledgements}

We thank the financial support of CNPq (Proc. 483455/2013-0) and Fundação Araucária de Apoio ao Desenvolvimento Científico e Tecnológico do Estado do Paraná (Conv. 675/2014), and the curator of the Herbarium SP (Instituto de Botânica, São Paulo) for loan of material.

\section{References}

Alves CR, Cortez VG. 2016 - Gasteroid Phallomycetidae (Basidiomycota) from Parque Estadual São Camilo, Paraná, Brazil. Iheringia, Série Botânica 71, 27-42.

Bononi VLR, Guzmán G, Capelari M. 1984 - Basidiomicetos do Parque Estadual da Ilha do Cardoso. V: Gasteromicetos. Rickia 11, 91-97.

Braun B. 1932 - Estudo sobre as Phalloideas Riograndenses. Relatório do Ginásio Anchieta 1932, $5-28$.

Calonge FD. 1998 - Gasteromycetes. I. Lycoperdales, Nidulariales, Phallales, Sclerodermatales, Tulostomatales. Flora Mycologica Iberica 3, 1-271.

Calonge FD. 2005 - A tentative key to identify the species of Phallus. Boletin de la Sociedad Micológica de Madrid 29, 9-17.

Cortez VG, Rossoni MG. 2014 - Dog intoxication by lizard's claw mushroom, Lysurus cruciatus (higher Basidiomycetes) in Southern Brazil. International Journal of Medicinal Mushrooms 16, 269-271.

Cortez VG, Baseia IG, Silveira RMB. 2011a - Gasteroid mycobiota of Rio Grande do Sul, Brazil: Lysuraceae (Basidiomycota). Acta Scientiarum, Biological Sciences 33, 87-92.

Cortez VG, Baseia IG, Silveira RMB. 2011b - Two noteworthy Phallus from southern Brazil. Mycoscience 52, 436-438.

Dennis RWG. 1953 - Some West Indian Gasteromycetes. Kew Bulletin 8, 307-328.

Dring DM. 1964 - Gasteromycetes of West Tropical Africa. Mycological Papers 98, 1-60.

Fischer E. 1928 - Untersuchungen über Phalloideeen aus Surinam. Vierteljahrsschrift der Naturforschenden Gesellschaft in Zurich 73, 1-39. 
Grgurinovic CA. 1997 - Larger Fungi of South Australia. The Botanic Gardens of Adelaide and State Herbarium \& The Flora and Fauna of South Australia Handbooks Committee, Adelaide.

Hemmes DE, Desjardin DE. 2002 - Mushrooms of Hawaii: an identification guide. Ten Speed Press, Berkeley.

Hemmes DE, Desjardin DE. 2009 - Stinkhorns of the Hawaiian Islands. Fungi 3, 8-10.

Kornerup A, Wanscher JH. 1978 - Methuen Handbook of Colour. $3^{\text {rd }}$ ed. Eyre Methuen, London.

Kour H, Yangdol R, Kumar S, Shardar YP. 2016 - Three species of Phallus (Basidiomycota: Agaricomycetes: Phallaceae) from Jammu \& Kashmir, India. Journal of Threatened Taxa 8, 8403-8409.

Kreisel H. 1996 - A preliminary survey of the genus Phallus sensu lato. Czech Mycology 48, 273281.

Magnago AC, Trierveiler-Pereira L, Neves MA. 2013 - Phallales (Agaricomycetes, Fungi) from the tropical Atlantic Forest of Brazil. The Journal of the Torrey Botanical Society 140, 236244.

Meijer AAR. 2006 - Preliminary checklist of the macromycetes from the state of Paraná, Brazil. Boletim do Museu Botânico Municipal (Curitiba) 68, 1-55.

Miller Jr. OK, Miller HH. 1998 - Gasteromycetes: morphological and development features. Mad River, Eureka.

Rick J. 1961 - Basidiomycetes Eubasidii no Rio Grande do Sul - Brasilia 6. Iheringia, Série Botânica 9, 451-480.

Sandoval-Leiva P, Henríquez JL, Trierveiler-Pereira L. 2014 - Additions to the Chilean phalloid mycota. Mycotaxon 128, 45-54.

Spegazzini C. 1887 - Las falóideas argentinas. Anales de la Sociedad Científica Argentina 24, 5968.

Sulzbacher MA, Cortez VG, Baseia IG. 2013 - Rediscovery of Pseudocolus garciae in southern Brazil. Mycotaxon 123, 113-119.

Trierveiler-Pereira L. 2015 - Phalloid fungi (Phallales) of Brazil. Field Museum Field Guide 716. http://fieldguides.fieldmuseum.org/sites/default/files/rapid-color-guides-pdfs/716_brazilphalloid_fungi.pdf (accessed 28 June 2016).

Trierveiler-Pereira L, Loguercio-Leite C, Calonge FD, Baseia IG. 2009 - An emendation of Phallus glutinolens. Mycological Progress 8, 377-380.

Trierveiler-Pereira L, Alves CR, Silveira RMB. 2014a - The genus Blumenavia (Clathraceae, Phallales). Mycosphere 5, 496-501.

Trierveiler-Pereira L, Meijer AAR, Hosaka K, Silveira RMB. 2014b - Updates on Protubera (Protophallaceae, Phallales) and additional notes on P. maracuja. Mycoscience 55, 35-42.

Wright JE. 1960 - Notas sobre Faloideas Sud y Centroamericanas. Lilloa 30, 339-359. 